\title{
EFFECTS OF LEADER-MEMBER EXCHANGE, INTERPERSONAL RELATIONSHIP, INDIVIDUAL FEELING OF ENERGY AND CREATIVE WORK INVOLVEMENT TOWARDS TURNOVER INTENTION: A PATH ANALYSIS USING STRUCTURAL EQUATION MODELING
}

\author{
Muhammad Shahnawaz Adil ${ }^{1 *}$ and Ayesha Awais ${ }^{2}$ \\ ${ }^{1}$ Department of Management Sciences, IQRA University, Karachi-75300, Pakistan \\ ${ }^{2} M B A$ Graduate, Department of Management Sciences, IQRA University, \\ Karachi-75300, Pakistan \\ ${ }^{*}$ Corresponding author: adil.s@iuk.edu.pk
}

Published online: 30 December 2016

To cite this article: Adil, M. S., and Awais, A. (2016). Effects of leader-member exchange, interpersonal relationship, individual feeling of energy and creative work involvement towards turnover intention: A path analysis using structural equation modeling. Asian Academy of Management Journal, 21(2), 99-133. http://dx.doi.org/10.21315/ aamj2016.21.2.5

To link to this article: $\mathrm{http}: / / \mathrm{dx}$.doi.org/10.21315/aamj2016.21.2.5

\begin{abstract}
This study investigates the impact of leader-member exchange (LMX), interpersonal relationship, individual feeling of energy and creative work involvement on turnover intention. A sample of 300 respondents is drawn from the manufacturing sector of Karachi. Confirmatory factor analysis is used to assess the reliability and validity of the measurement model. Structural equation modeling method was applied to test the six hypotheses. The results show that interpersonal relationship is positively related with turnover intention. LMX is positively related with individual feeling of energy which is in turn, positively related with creative work involvement. Moreover, LMX is found negatively related with turnover intention. In particular, LMX and creative work involvement have shown an insignificant impact on interpersonal relationship and turnover intention respectively. The managerial implications and areas for future research are discussed.
\end{abstract}

Keywords: leader-member exchange (LMX), interpersonal relationship, individual feeling of energy, creative work involvement, turnover intention, manufacturing, Pakistan. 


\section{INTRODUCTION}

In organisational studies, theorists have placed a great deal of importance in identifying better ways for developing employee's performance as well as increasing their job satisfaction (e.g., Eatough, Chang, Miloslavic, \& Johnson, 2011; Örtqvist \& Wincent, 2006; Podsakoff, LePine, \& Lepine, 2007). In fact, these two strategic objectives usually pose a considerable amount of looming pressure on all of its stakeholders which could turn out to be a cause of severe financial distress if they are not managed adequately on time. It is because of the fact that financial gains or losses are closely related with employee's job performance and satisfaction (Becker \& Huselid, 2006; Huselid, 1995).

Indeed, a satisfied portfolio of employees brings innovative ideas in order to reconstruct established ways through which organisational effectiveness could be observed while being within the financial constraints. The employees' attitude of creative work involvement is largely influenced by their individual feeling of energy which is often considered as a product of good in-group relationship between the member and the leader (Tierney, Farmer, \& Graen, 1999). Moreover, this leader-member exchange (henceforth, LMX) relationship affects the interpersonal relationship by establishing a constructive relationship to achieve higher level of efforts (Bae, 1997; Gerstner \& Day, 1997). In short, this is the LMX relationship which could either reduce or increase employee's turnover intentions.

It is however, very important to understand the importance of in-group LMX relationship between employees and their superiors (Dulebohn, Bommer, Liden, Brouer, \& Ferris, 2012). A number of strategic and operational outcomes emerge from the nature of LMX relationship. In other words, annual targets may be achieved on time because of effective communication and better utilisation of available resources (Adil, 2015). A considerable amount of communication gap often results in high power distance between the two entities (Hofstede, 1983) which is reflected in the form of organisational ineffectiveness. Similarly, if LMX relationship does not thrive any feeling of energy among employees then the creative work involvement will highly be questioned. Since the employees do not receive any supportive guidelines because of lack of facilitation from the superiors, they not only concentrate on securing their job but also tend to perform minimum acceptable level of work performance. Eventually, it becomes very challenging for the HRM professionals to reduce high turnover intentions (Aghazadeh, 1999). In short, a poor LMX relationship not only adversely affect the financial and nonfinancial outcomes but also create a sense of apathy in achieving assigned targets. Therefore, it is important to realise the critical nature and significance of LMX relationship in better combatting with turnover intentions (Lee \& Heard, 2000). 
Karachi being the largest business and financial hub of Pakistan attracts a number of multinational companies in a rapidly-growing industry sectors of manufacturing e.g. pharmaceuticals and bio-technology, automotive and spare parts, etc. These manufacturing companies require skilled engineering and technical staff. Considerable amount of this industry demands is satisfied by a few number of engineering universities and polytechnic institutes operating in the city. However, with the advent of state-of-the-art technologies in the manufacturing operations predominantly owned by foreign multinational corporations in Karachi, there has been an increasing need of highly-skilled graduate engineers, technicians, and technologists. Moreover, this situation has become very challenging for the employers since 1990s because the manufacturing industries faced a high rate of employees' turnover in their organisations. Indeed, a considerable amount of semiand highly-skilled technologists and graduate engineers started to leave the country to avail better job opportunities particularly in the Gulf region. The industry also observed that these skilled people even left their permanent jobs in Karachi and preferred to work on (interim) contract basis abroad.

Soon, the top management realised this high rate of employees' turnover as one of the biggest challenges and started to take certain measures to address this indispensable situation. One of the most important measures is to realise the importance of high-quality in-group' relationship between the leader and the member (i.e. LMX relationship). The top management started to believe that the high rate of turnover intention may be effectively mitigated by improving LMX relationship. In addition, very positive results may be observed with this social and occupational support (Kailasapathy, Kraimer, \& Metz, 2014). This LMX relationship due to improved communications may also reduce role stressors and turnover intention and improve job satisfaction (Firth, Mellor, Moore, \& Loquet, 2004; Zhang, Tsingan, \& Zhang, 2013).

Based on the above discussion, it has been identified that the impact of LMX relationship on turnover intentions has been an under-research area in the context of Pakistan. Very recently, Michel and Tews (2016) have also concluded that LMX relationship needs further elucidation. In the context of Pakistan, scant piece of literature is available in which LMX relationship was studied in varied contexts with different constructs (e.g., Ashraf, Jaffri, Riaz, \& Khan, 2012; Ishaq, Hussain, Nawaz, Asim, \& Cheema, 2012; Imran \& Fatima, 2013; Ismail, Jafri, \& Khurrum, 2011; Kashif, Khan, \& Rafi, 2011; Nazir, Aslam, \& Nawaz, 2011; Shaukat, Senin, $\&$ Ahmed, 2012). However, we found the study of Saeed, Waseem, Sikander, and Rizwan (2014) slightly relevant who investigated LMX relationship in collaboration with other variables (namely, job satisfaction, performance, emotional intelligence, 
and organisational commitment) to predict turnover intentions in Bahawalpur district of Punjab (Pakistan).

To the best of our knowledge, we found no empirical evidence which has investigated the impact of LMX relationship on turnover intentions having the multi-level unidirectional effect on interpersonal relationship, individual feeling of energy, and creative work involvement in the context of Pakistan. This precisely forms the objectives of the present study that has been constructed to bridge the knowledge gap in the manufacturing sector of Karachi, in particular. Therefore, the present study aims to answer the following research question:

\section{Research Question}

How well can we predict turnover intention from using a combination of four variables: leader/member exchanger relationship, interpersonal relationship, individual feeling of energy, and creative work involvement in the manufacturing companies of Karachi?

\section{THEORETICAL FRAMEWORK AND HYPOTHESES}

When an individual joins a team, the vertical dyadic relationship is established that involves three sequential stages: Role-taking, role-making, and routinisation. Initially after becoming a team member, the incumbent serves in an unknown zone in the eyes of superiors. Therefore, in the role-taking stage, the leader provides opportunities to evaluate the member's competencies with the aim to know which specific business areas the individual could be best fit in. thus, in the role-making stage, the leader sets up an appropriate role for the member. According to LMX theory, this is the stage where the leader often subconsciously classifies the member either in 'in-group' or 'out-group' zones. The bases of this selection include ability to prove loyal, trustworthiness, and the level of skills the member holds. Finally, the stage of routinisation arrives where the leader starts to have a strong believe about the member. In general, members are inquisitive to know how their leader feels about themselves. In-group members start to enjoy a wide range of benefits hence they tend to maintain every possible act through which they could sustain their privileged position. In contrast, members in out-group sphere start to dislike their leader because they strongly believe that it seems impossible for them to enter in-group circle now. 


\section{Leader-Member Exchange and Interpersonal Relationship}

According to LMX theory, leaders treat their subordinates differently according to the quality of their affiliations (Dienesch \& Liden, 1986). The theory of coordination tells the association among energy and interpersonal connections (Quinn \& Dutton, 2005), as the "interplay of speech acts and energy" (Quinn, 2007, p. 79). The theory proposed a positive engagement and conversation between people together with maximising the energy towards having the sense of belonging, autonomy and competency. LMX is a leadership key which highlights the quality of relationship between a manager and subordinates. In fact, when leaders and members have a mature relationship that ultimately gives benefits to both parties, it creates effective leadership (Graen \& Uhl-Bien, 1995). This theory is based on dyadic relationship between leader and members having the central idea that superiors develop either positive or negative relationships with their subordinates (Graen \& Scandura, 1987).

The interpersonal relationship is an integral part of determining effectiveness (Rogers, 1962) which has a direct univariate connection with LMX theory. In fact, because of the high-quality in-group LMX relationship, the employees (followers) start to perceive that their supervisor (leader) seems serious in their professional growth hence, $\mathrm{s} /$ he provides a number of privileges for the said cause. This social exchange between the leader and the members originates different opportunities for the members so that they could remain satisfied in achieving organisational effectiveness and required outcomes on time (Horne, Plessis, \& Nkomo, 2015). This social support (Eisenberger, Stinglhamber, Vandenberghe, Sucharski, \& Rhoades, 2002) extends a variety of opportunities for the members including timely access to necessary information, high mutual trust and respect (Northouse, 2013).

Previous studies (e.g., Bauer \& Green, 1996; Graen \& Scandura, 1987) have shown that in LMX relationship leaders develop dissimilar type of associations with their followers in the same group. However, in interpersonal relationships quality is more important than quantity at times, as relations varies between individuals (Jones, 1982). It develops emotional and occupational stress among 'out-group' subordinates because of the sense of isolation by their leaders (Cacioppo, Hawkley, Ernst, Burleson, Berntson, Nouriani, \& Spiegel, 2006; Cacioppo \& Patrick, 2008; Rook, 1984; Rotenberg, Addis, Betts, Corrigan, Fox, Hobson, Rennisonm, Trueman, $\&$ Boulton, 2010). In short, the LMX relationship has a direct connection with the development of interpersonal relationship (Ansari, 1986). It provides accessible developmental opportunities for the members of the organization (Sturges, Guest, Conway, \& Mackenzie, 2002). Access to these valuable resources depends on 
the interpersonal relationship between the leader and the followers (Adil, 2014; Sparrowe \& Liden, 1997). Hence, the following hypothesis is posited:

H1: LMX relationship is positively associated with interpersonal relationship.

\section{Interpersonal Relationship and Turnover Intention}

According to LMX theory, individual employee creates a unique dyadic level of interpersonal association/relationship with the manager (Gerstner \& Day, 1997). The LMX quality relationship ranges from low to high. High-quality LMX is characterized by high degree of respect, mutual trust and obligation between both entities (Graen \& Uhl-Bien, 1995). Followers receive privileges and special attention (e.g., get access to information), career-improving opportunities (e.g., special work project), and increased level of autonomy from the leader for performing their routine jobs (Wang, Law, Hackett, Wang, \& Chen, 2005). In essence, LMX relationship acts as a motivating factor for employees in the job context, which does not only increase the job satisfaction but also improving the quality of work they perform (Tierney et al., 1999). Indeed, employees show their affective commitment when they 'want to' stay in the organization at their will (Meyer \& Allen, 1997) which may predict employee's turnover intention (Kuean, Kaur, \& Wong, 2010). Numerous authors (e.g. Ashar, Munir \& Hafeez, 2013; Irfan, Farhat, Hamid, \& Nawaz, 2013; Salleh, Nair \& Harun, 2012; Jehanzeb, Rasheed \& Rasheed, 2013) have concluded that the intention to leave is decreased when affective commitment is high. Moreover, Khan, Nawaz, Khan, Khan, Khan, and Yar (2014) identified that a relationship between expenditure on worker development and intent to leave is fully mediated by affective commitment and job satisfaction (Ashar et al., 2013; Ghosh, Satyawadi, Joshi, \& Shadman, 2013). In short, there are a number of salient facets which constitute in predicting intention to leave. To reflect a major account of this complex phenomenon, the founding relationship between the leader and the member plays a key role. Therefore, besides other important factors, one should not condone the importance of high job satisfaction and increased affective commitment in order to decrease the turnover intention of key employees, in particular. Accordingly, high LMX relationship increases job satisfaction thereby decrease turnover intention.

By focusing on the dyadic relationship between leader and members, Graen, Liden, and Hoel (1982) revealed that turnover and leadership was in fact a result of employee's interpersonal relationships with his/her superiors, which they considered as LMX. Moreover, members in high LMX relationship have high level of trust, support, and other benefits from leader causing less intention to 
leave the organization (Vecchio, 1985; Ferris, 1985). Therefore, Gerstner and Day (1997) argued that both LMX and turnover intention have negative correlation that is largely influenced by interpersonal relationships. Furthermore, Baumeister and Leary (1995) identified that belongingness, the need to form and maintain interpersonal relationships constitute as leading fundamental aspects of motivations behind human behavior.

In contrast, 'too-good' relationship with supervisors actually increases an employee's charm to the external labor market causing an increase in their intention to leave the firm preferably on voluntary basis (Abbasi \& Hollman, 2000; Morrow, Suzuki, Crum, Ruben, \& Pautsch, 2005). This discussion leads to suggest the following hypothesis:

H2: Interpersonal relationship is positively related with turnover intention.

\section{Leader-Member Exchange and Individual Feeling of Energy}

The three stages (role-taking, role-making, and routinisation) reflect the quality of relationship that depends on energy and liveliness of individuals. As discussed earlier, in-group members demonstrate positive self-esteem, confidence in achieving goals, and energetic contribution as they are given more and better opportunities than out-group members. Thus, individuals of in-group are motivated enough to show more involvement and competencies to perform better than the past. This is largely because of the individual feeling of energy among in-group members that is continuously reinforced by the leader. It further magnifies the achievable targets which enables both members and the leader to make 'well-informed' decision on time. Similarly, high-quality exchanges are in fact a friendly-working relationship which is typified by mutual trust and support (Liden \& Graen, 1980), interpersonal attraction (Dansereau, Graen \& Haga, 1975), loyalty and bidirectional influence (Dienesch \& Liden, 1986).

Indeed, energy is a kind of capability that forces individuals to act on a situation. When there is a positive energy among individuals, it stimulates the positive behavior as employees feel good to do a particular task. In contrast, when the energy is low, it will reflect on their performance. People with high LMX relationship usually experience more energy and positive attitude at work (e.g., interest, joy, and dedication). This illustrates that members have intellectual capacity to better perform on official assignments because of positive feelings, intrinsic motivation, self confidence, and additional value-added efforts. Positive feelings are the behavioral approach (Amabile, Schatzel, Moneta, \& Kramer, 
2004) which increases the readiness for performance (Forgas, 2003) on the bases of sharing creative thoughts and immediate attention from rest of the individuals in the group. The positive feeling creates energy which is transformed into positive actions. Thus, the following hypothesis is formulated.

\section{H3: LMX relationship is positively associated with individual's feeling of energy.}

\section{Individual Feeling of Energy and Creative Work Involvement}

Previous studies (e.g., Amabile, Schatzel, Moneta, \& Kramer, 2004) have revealed that creative behavior needs much more energy and time. Motivation assimilates real energy among members that leads them in building creative work behaviours. Spreitzer, Sutcliffe, Dutton, Sonenshein, and Grant (2005) focused on positive causes of energy in making loveliness to exert creative behaviors. The experiences of positive feelings leads to creativity (Darvish, \& Dokht, 2011). Positive mood experiences the feeling, which leads to thinking and experience self-creative actions in person.

The root of senses found in individual's relationships. Talk to each other and having interactions with one another leads to create individual liveliness or energy at work. In other words, joy is a desire that comes from relationship and exchange with others. When there is an absence of energy, creativity will not improve or grow and subordinate participate less in creative activities. In creativity, employees are involved in the invention of useful and novel ideas to improve products, processes, services, and operations so that firm could better address inevitable changes and handle uncertainty in the hyper-competitive market (Gilson, Shalley, \& Ruddy, 2005). Previous studies (e.g., Dutton, 2003; Quinn \& Dutton, 2005) have found that individual feeling of energy enhances creative work involvement however, special working conditions and member's professional background may not be condoned (Polewsky \& Will, 1996).

The question is how do managers energize their team members to get them involved in creative work? Previous researchers (e.g., Volmer, Spurk, \& Niessen, 2012) have given some attention on how managers provides the impetus for employee creativity in the organization (e.g., Doyague, \& Nieto, 2012). Noticeably, Amabile's (1983) 'componential theory of creativity' serves as the theoretical basis for the claim that leaders stimulate creativity and innovation through their industry acumen, emotional intelligence, technical skills, talent to support their subordinates in managing routine and complex projects. It not only enhances level of motivation among the members but also develops their expertise. 
The behaviors serves as role model; shows openness to new concepts and ideas, planning and goal setting with appropriate manner and supports the work team to observe quality communication and interaction with coworkers with their constructive feedback (Amabile et al., 2004). These supportive behaviors of leadership constitute both relationship- and task-oriented actions that increase one's enthusiasm to get involved in creative work. Hence the following hypothesis is advised:

H4: Individual's feeling of energy is positively related with creative work involvement.

\section{Creative Work Involvement and Turnover Intention}

Employee's turnover is a costly event for an organization and has direct linkage with organizational performance thus the subject has received much attention in human resource management and organizational studies (Harris, Kacmar, \& Witt, 2005; Hom \& Griffeth, 1991). Creative work involvement is an important predictor of turnover intention because it entails a complex experience that requires an interactional loom (Amabile, 1996; Woodman, Sawyer, \& Griffin, 1993; Zhou \& Shalley, 2003) hence they invest their time and resources in creative process to improve their work (Atwater \& Carmeli, 2009; Carmeli \& Schaubroeck, 2007).

According to previous studies, there is a negative relationship between creativity and turnover intentions but employee turnover intentions are not the same as real turnover. Voluntary turnover intention is important within its own right for many reasons. The viewpoint of social identity has shown to illuminate the individual behaviors based on motivation (Ashforth, Harrison \& Corley, 2008; Blader \& Tyler, 2009; Olkkonen \& Lipponen, 2006; Riketta, 2005; Tyler and Blader, 2000; Van Knippenberg \& Ellemers, 2003). With respect to this perspective, organizational identification could influence performance results as creativity, extra-role behaviors and intention to leave (Blader \& Tyler, 2009; Hirst, van Dick, \& van Knippenberg, 2009; Riketta, 2005). One of the studies argued that psychological climate for innovation (PCI) may motivate intrinsically the salespeople to gain and learn new knowledge and job related skills which is an experience that fulfills and enhances the job satisfaction. Employee job satisfaction and learning, in turn, affects creativity and turnover intentions.

From the perspective of referent cognitions model (Aquino, Griffeth, Allen, \& Hom, 1997), PCI is viewed as a factor that increases the chances of amelioration as creative/innovative organizations. It is perceived as those firms which adapt changes and have a good chance of survival in upcoming future. Therefore, the 
conceptualised model formed a positive relationship between PCI and creativity and a negative association between PCI and voluntarily turnover intention. However, the relationships are mediated by job satisfaction and learning orientation partially.

Creativity needs some substantial amount of freedom (Wang \& Ma, 2013). Autonomy and freedom are experienced by individuals who are generally encouraged by engaging themselves in creativity (Hackman \& Oldham, 1980). Moreover, Spreitzer (1995) discussed psychological empowerment in four cognitions as meaningfulness (the purpose of a goal), competence (the ability to perform on given assignments), self-determination (a tendency of taking initiatives), and impact (the degree to which an individual can control the outcomes). Based on above discussion, the following hypothesis is suggested: $\mathrm{H}_{5}$ : Creative work involvement is negatively associated with turnover
intention.

\section{Leader-Member Exchange and Turnover Intention}

In contrast with other leadership theories, LMX theory is expressed in terms of the interpersonal relationship (Davis \& Gardner, 2004; Graen \& Uhl-Bien 1995; Cropanzano \& Mitchell, 2005; Ferris, Brown, \& Heller, 2009). This theory has more impact on both individuals and the organization (Ishak \& Alam, 2009). In fact, highquality LMX involves a higher level of trust between parties, emotional support and higher-order benefits to in-group members (Dansereau et al., 1975; Dienesch \& Liden, 1986). In contrast, low-quality LMX relationship is characterized by lack of trust, dishonesty, poor communication and comparatively less benefits and rewards to the out-group members which results in unstable or negative affective comebacks towards their organization (Kristof-Brown, Zimmerman, \& Johnson, 2005). Therefore, high-quality LMX relationship discourages members to leave the organisation.

Previous studies have recognized the importance of the quality of LMX relationship in reducing turnover intention (Elanain, 2014; Gaertner, 1999; Ghosh, Reio, \& Bang, 2013; Ghosh et al., 2013; Morrow et al., 2005) and provide strong evidence that the quality of LMX is negatively related with turnover intentions (Ansari, Hung, \& Aafaqi, 2007; Gerstner \& Day, 1997; Griffeth, Hom, \& Gaertner, 2000; Harris et al., 2005; Jordan \& Troth, 2011; Morrow et al., 2005). Hence, the following hypothesis is constructed:

$\mathrm{H}_{6}$ : LMX relationship is negatively associated with turnover intention. 


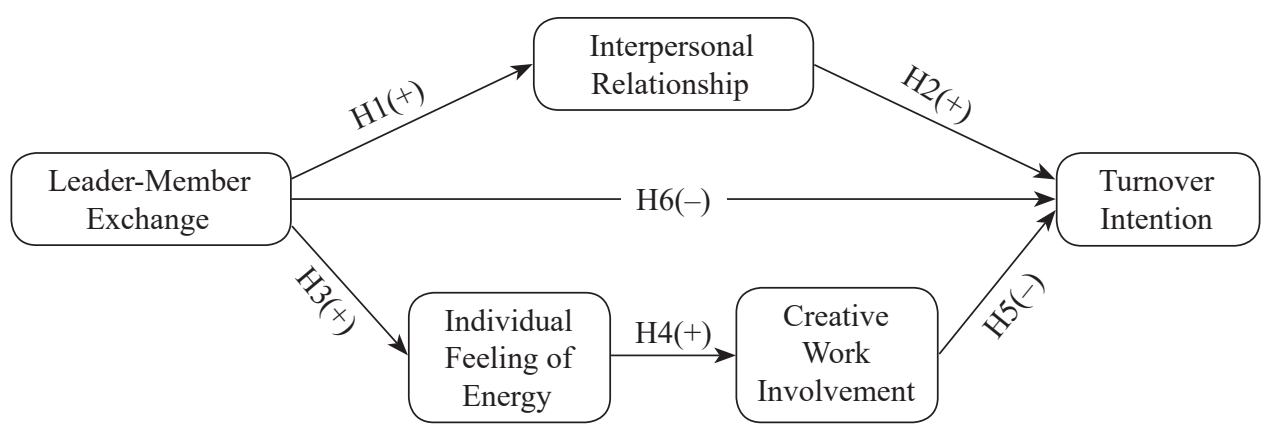

Figure 1. Conceptual Framework of the Present Study

\section{METHOD}

\section{Sample and Data Collection}

A sample of 300 responses is drawn from the manufacturing companies operating in Sindh Industrial Trading Estates (SITE) Karachi by using a self-completion questionnaire with non-probability convenience sampling (Gray, 2004). There are over 59 godowns and 3,000 plots spread over a total area of 4,700 acres covering approximately 60.5 miles length of roads. All of these manufacturing companies were registered with Karachi Chamber of Commerce and Industry (KCCI). Table 1 tabulates the composition of the sample drawn:

\section{Measures}

The study is comprised of five constructs namely, LMX, interpersonal relationship, individual feeling of energy, creative work involvement, and turnover intention. With no sub-scales, the self-completion questionnaire included a total of 33 items that was measured on a five-point Likert scale ranging from 1 (strongly disagree) to 5 (strongly agree).

\section{Leader-Member Exchange}

The study adapted six items from Lee, Scandura, Kim, Joshi, and Lee (2012) to measure LMX. Sample items include "My Leader recognizes my potential well enough," and "I can depend on my supervisor at his expense when I really need it". Cronbach's alpha was 0.80 (6 items). 
Table 1

Profile of respondents for survey

\begin{tabular}{llcc}
\hline Demographics & Category & Frequency & Percentage (\%) \\
\hline Gender & Male & 204 & 76.7 \\
Age & Female & 62 & 23.3 \\
& Less than 25 Years & 55 & 20.7 \\
& 25 to 30 & 105 & 39.5 \\
& 31 to 35 & 39 & 14.7 \\
36 to 40 & 29 & 10.9 \\
41 to 45 & 29 & 10.9 \\
46 to 50 & 7 & 2.6 \\
Marital Status & above 50 & 2 & .8 \\
& Single & 149 & 56.0 \\
& Married & 117 & 44.0 \\
& Diploma & 21 & 7.9 \\
Level of responsibility & Bechelor's degree & 79 & 29.7 \\
& Master's degree & 138 & 51.9 \\
& others & 28 & 10.5 \\
& Non managerial staff & 56 & 21.1 \\
& Supervisor & 61 & 22.9 \\
& Middile management & 120 & 45.1 \\
& Senior management & 29 & 10.9 \\
& Less than 2 years & 67 & 25.2 \\
& Between 2 to 5 years & 56 & 21.1 \\
& More than 5 years & 143 & 53.8 \\
\hline \multirow{3}{*}{ Experience } & & &
\end{tabular}

Source: Analysis of survey data $(n=266)$

\section{Interpersonal Relationship}

To measure interpersonal relationships, items were adapted from Darrow, Callaghan, Bonow and Follette (2014). Sample items include "People don't like the way I ask for things," "I have problems being close to others". Cronbach's alpha was 0.87 (8 items).

\section{Individual Feeling of Energy}

Seven items were adapted from Shirom-Melamed Vigor Measure (SMVM; Shirom, 2003). Sample items include "I feel energetic," "I feel I am able to contribute new ideas". Cronbach's alpha was 0.87 (7 items). 


\section{Creative Work Involvement.}

Seven items were taken from Carmeli and Schaubroeck (2007) to measure creative work involvement. Sample items include "I solved problems that had caused other difficulty," "I tried out new ideas and approached to problems". Cronbach's alpha was 0.80 ( 7 items).

\section{Turnover Intention}

This construct was measured by adapting items from Liu, Cai, Li, Shi, and Fang (2013) and Bushra (2012). Sample items include "I often feel that I should quit," and "As soon as possible, I will leave the organization". Cronbach's alpha was 0.93 (5 items).

\section{Ethical Considerations}

The study incorporated different ethical measures as suggested by Bryman (2008) and Dillman (1978) for drawing the sample using a questionnaire. In order to avoid any potential harm coming to the respondents, it was ensured that the identification of respondents should not be discernible through any means and their individual participation is voluntary. Moreover, the aims and objectives were also clearly explained in a covering letter enclosed with each questionnaire. Before filling in the questionnaire, all of them were aware of the fact that there was not sponsor to the study and the results would solely be used for academic purpose only.

\section{DATA ANALYSIS AND RESULTS}

The data were analysed by using the 22nd version of both Statistical Package for Social Sciences (SPSS) and Analysis of Moment Structure (AMOS). Firstly, the issue of common method bias was examined by using SPSS. Then an exploratory factor analysis (EFA) was performed to classify 33 Likert-scale questionnaire items into the required 5 factors (i.e. leader-member exchange, interpersonal relationship, individual feeling of energy, creative work involvement, and turnover intention). After that, the internal consistency or reliability (Cronbach alpha) of each factor was computed. Then AMOS application was used to perform confirmatory factor analysis which developed a measurement model highlighting the composite reliability (CR) and average variance extracted (AVE) to assess both reliability and validity measures of each of the five constructs. Based on the measurement model, AMOS application was further used to construct a structural model by using structural equation modeling in order to test the six hypotheses. The details of these statistical techniques are described below: 


\section{Examination of Common Method Variance}

Since the data were collected by using one common method (i.e. self-completion questionnaire), there may be a potential occurrence of common method variance (CMV) due to this one-method bias. It is therefore, important to analyze CMV so that we could control over its effects in mono-method research designs (Sharma, Crawford, \& Yetton, 2009). Noticeably, Podsakoff, MacKenzie, and Podsakoff (2012) argued that numerous behavioral studies have condoned to assess CMB before data analysis. It may not only cause potential problems but also there is probability of reporting method-biased results.

Likewise previous studies (e.g., Andersson \& Bateman, 1997; Aulakh \& Gencturk, 2000; Greene \& Organ, 1973; Organ \& Greene, 1981; Schriesheim, 1979), this study used Harman's single-factor (or one-factor) test to investigate CMV before any data analysis. For this, we performed exploratory factor analysis in SPSS version 22 and requested SPSS to load all of the 33 Likert-scale items onto a single factor. Podsakoff et al. (2012) advised to assess whether this one factor accounts for majority (say, more than 50 percent) of the total variance in the unrotated factor solution. The result of Harman's single-factor test reveals that one single factor in this study accounted for only $21.63 \%$ of the total variance which is less than $50 \%$ threshold value. It shows that there is no manifestation of the presence of common method variance in this study. It warrants that we can proceed further for data analysis as discussed below:

\section{Investigation of Univariate and Multivariate Outliers}

During initial data screening phase, a total of 34 univariate and multivariate outliers were detected and removed from the dataset by using standardised (Z) score (cutoff absolute value |3.29|) and CDF.CHISQ function (Mahalanobis D ${ }^{2}$, $p<.001$ ), respectively. In fact, Tabachnick and Fidell (2007) stated "Cases with standardized scores in excess of $3.29(p<.001$, two-tailed test) are potential outliers" (p. 73). It resulted in a sample of 266 (i.e. 300-34) useable responses for data analysis resulting a response rate of $88.67 \%$.

\section{Exploratory Factor Analysis}

Exploratory factor analysis was performed by using Principal Component method of factoring to classify 33 Likert-scale items onto the required five dimensions (or factors). In fact, these five factors are the ones which are used in the conceptual framework of the study (Figure 1). The value of Kaiser-Meyer-Olkin measure of sampling adequacy was 0.821 which clearly reflects that there are sufficient items for each component. A minimum value of 0.70 was suggested by Leech, 
Barett, and Morgan (2005). The Bartlett's Test of Sphericity (approx. Chi-Square = 5190.739 , degree of freedom $=496, p<0.001$ ) depicts that "the correlation matrix is significantly different from an identity matrix, in which correlations between variables are all zero" (Leech et al. 2005, p. 80). Moreover, Tabachnick and Fidell (2007) stated "In the Bartlett method, factor scores correlate only with their own factors and the factor scores are unbiased (that is, neither systematically too close nor too far away from "true" factor scores)" (p. 651).

Moreover, the initial solution was further rotated through varimax orthogonal (uncorrelated) rotation with Kaiser Normalisation method to improve readability of the factor loadings. The objective was to extract five uncorrelated factors so that all of the 33 Likert-scale items should be loaded onto its respective factor only. Varimax method of rotation was requested because it "... is a variance maximizing procedure. The goal of varimax rotation is to maximize the variance of factor loadings by making high loadings higher and low ones lower for each factor" Tabachnick and Fidell (2007, p. 620). Factor loadings less than $|0.40|$ were omitted thus, a total of 32 items were loaded onto their respective factors (or variables) having a very strong construct and convergent validity (Tharenou, Donohue, \& Cooper, 2007) as shown in Table 2.

Table 2 shows eigenvalues, percentage of variance, cumulative percentage explained and total number of items loaded of the final rotated solution which was emerged in six iterations. It can be noticed that all of the eigenvalues for each factor is more than one and each factor (after orthogonal rotation) explained a good amount of individual variance. These five factors explained cumulatively accounted for 59.84 (approx. 60) percent of the total variance. Only the third LMX item "My leader recognizes my potential well enough" was not loaded because of its low factor loading. Discriminant validity was also achieved as there was no cross-loadings in the rotated components matrix (Tharenou et al. 2007). The following section describes the Pearson correlation analysis and reliability statistics of the extracted variables.

\section{Correlational Analysis and Reliability Statistics}

Table 3 shows mean, standard deviation, correlation analysis and reliability statistics of the five variables emerged after exploratory factor analysis. Due to orthogonal rotation, the table shows a low inter-variable correlation (r) thus, shows no sign of multicollinearity. In addition, the coefficients of reliability statistics (Cronbach Alpha) for each variable are listed on the diagonal in parentheses. All of the reliability coefficients are well above the 0.70 threshold limit. The overall reliability of the 32 items loaded after exploratory factor analysis was 0.833 . 
Table 2

Exploratory Factor Analysis $(N=266)$

\begin{tabular}{|c|c|c|c|c|c|}
\hline & IPR & IFE & TOI & CWI & LMX \\
\hline IPR_3 & 0.872 & & & & \\
\hline IPR_2 & 0.866 & & & & \\
\hline IPR_7 7 & 0.850 & & & & \\
\hline IPR_5 & 0.843 & & & & \\
\hline IPR_1 & 0.732 & & & & \\
\hline IPR_4 & 0.534 & & & & \\
\hline IPR_8 & 0.524 & & & & \\
\hline IPR_6 & 0.434 & & & & \\
\hline IFE_3 & & 0.870 & & & \\
\hline IFE_2 & & 0.827 & & & \\
\hline IFE_1 & & 0.806 & & & \\
\hline IFE_7 & & 0.697 & & & \\
\hline IFE_4 & & 0.608 & & & \\
\hline IFE_6 & & 0.463 & & & \\
\hline IFE_5 & & 0.455 & & & \\
\hline TOI_3 & & & 0.934 & & \\
\hline TOI_4 & & & 0.876 & & \\
\hline TOI_1 & & & 0.860 & & \\
\hline TOI_5 & & & 0.854 & & \\
\hline TOI_2 & & & 0.837 & & \\
\hline CWI_5 & & & & 0.787 & \\
\hline CWI_4 & & & & 0.731 & \\
\hline CWI_3 & & & & 0.679 & \\
\hline CWI_6 & & & & 0.653 & \\
\hline CWI_2 & & & & 0.647 & \\
\hline CWI_1 & & & & 0.476 & \\
\hline CWI_7 & & & & 0.473 & \\
\hline LMX_2 & & & & & 0.743 \\
\hline LMX_5 & & & & & 0.689 \\
\hline LMX_6 & & & & & 0.665 \\
\hline LMX_1 & & & & & 0.646 \\
\hline LMX_4 & & & & & 0.614 \\
\hline Eigenvalues & 4.426 & 4.060 & 4.050 & 3.509 & 3.103 \\
\hline$\%$ of Variance & 13.83 & 12.69 & 12.66 & 10.97 & 9.70 \\
\hline Cumulative \% & 13.83 & 26.52 & 39.17 & 50.14 & 59.84 \\
\hline
\end{tabular}

Notes: Extraction Method: Principal Component Analysis.

Rotation Method: Varimax with Kaiser Normalisation.

Factor loadings less than $|0.40|$ are omitted to maintain clarity.

IPR = Interpersonal Relationship; IFE = Individual Feeling of Energy

TOI $=$ Turnover Intention; CWI $=$ Creative Work Involvement

LMX $=$ Leader-Member Exchange 
Table 3

Correlational Analysis and Reliability Statistics $(N=266)$

\begin{tabular}{lccccccc}
\hline & Mean & Std. Deviation & 1 & 2 & 3 & 4 & 5 \\
\hline Leader-Member Exchange & 3.99 & 0.52 & $(0.77)$ & & & & \\
Interpersonal Relationship & 3.32 & 0.77 & 0.017 & $(0.87)$ & & & \\
Individual Feeling of Energy & 4.15 & 0.48 & $0.474^{* *}$ & 0.030 & $(0.87)$ & & \\
Creative Work Involvement & 4.12 & 0.47 & $0.344^{* *}$ & $0.123^{*}$ & $0.480^{* *}$ & $(0.80)$ & \\
Turnover Intention & 3.21 & 1.01 & $-0.230^{* *}$ & $0.196^{* *}$ & $-0.183^{* *}$ & 0.059 & $(0.93)$ \\
\hline
\end{tabular}

Notes: ** Correlation is significant at the 0.01 level (2-tailed).

* Correlation is significant at the 0.05 level (2-tailed).

Cronbach Alpha coefficients for multi-item scales are listed on the diagonal in parentheses.

\section{Confirmatory Factor Analysis (Measurement Model)}

Anderson and Gerbing (1982, 1988), Fornell and Larcker(1981), and more recently, Hair, Black, Babin, and Anderson (2010) recommended that we should construct the CFA measurement model before the structural model is tested. Byrne (2010) notified that the measurement model depicts the links between the observed and unobserved variables. Therefore, the confirmatory factor analysis (CFA) was then performed in AMOS to validate the measurement model with the sample drawn. Out of 32 loaded items during EFA, only 17 items were left in the final solution of the CFA (measurement model). In contrast with Cronbach coefficient alpha, the composite reliability has been found to be a more suitable indicator of construct validity which measures the overall reliability of a collection of heterogeneous but similar items (Fornell \& Larcker 1981; Lin \& Lee 2004; Molina, Montes, \& RuizMoreno, 2007).

Table 4 shows the results of composite reliability (CR), average variance extracted (AVE) and inter-construct correlation separately for each of the five latent constructs. The AVE of each of the five constructs is greater than 0.50 showing a good convergent validity (Hair et al. 2010). Moreover, the square root of AVE of each latent construct is also greater than its inter-construct correlations with rest of the four constructs show very good discriminant validity (Molina et al. 2007). Lastly, each construct has very good composite reliability $(\mathrm{CR} \geq .70)$.

Besides, to check for the multicollinearity between predictors, Hair et al. (2010) argued that multicollinearity problem will be assumed if the inter-construct correlation exceeds .90. The highest coefficient value between individual feeling of energy and LMX is 0.535 , which is still less than the aforementioned threshold 
value (Table 4). Hence, it confirms that no multicollinearity problem exist among the latent constructs in the CFA measurement model (Hair et al., 2010; Lin \& Lee, 2004).

Table 4

CFA (Measurement Model): Reliability and Validity

\begin{tabular}{lcccccccr}
\hline & CR & AVE & $\begin{array}{c}\text { Square Root } \\
\text { of AVE }\end{array}$ & \multicolumn{5}{c}{ Inter-Construct Correlation } \\
\cline { 6 - 11 } & & & & 1 & 2 & 3 & 4 & 5 \\
\hline Interpersonal Relationship & 0.91 & 0.67 & 0.82 & 1 & & & & \\
Individual Feeling of Energy & 0.88 & 0.60 & 0.77 & -0.08 & 1 & & & \\
Turnover Intention & 0.91 & 0.76 & 0.87 & 0.23 & -0.15 & 1 & & \\
Leader-Member Exchange & 0.70 & 0.54 & 0.73 & -0.03 & 0.54 & -0.22 & 1 & \\
Creative Work Involvement & 0.76 & 0.61 & 0.78 & 0.16 & 0.44 & 0.04 & 0.42 & 1 \\
\hline
\end{tabular}

Notes: All values are rounded to two decimal places. $\mathrm{CR}=$ Composite Reliability; AVE = Average Variance Extracted

$\mathrm{AVE}=\left(\sum\right.$ squared standardised loading $) /\left(\sum\right.$ squared standardised loading $+\sum$ indicator measurement error $)$ $\mathrm{CR}=\left(\sum\right.$ standardised loading $) 2 /\left(\sum\right.$ standardised loading $) 2+\sum$ indicator measurement error $)$

where, indicator measurement error $=1-$ standardised loading

In addition to ratio of Chi-square statistics (i.e. minimum discrepancy or CMIN) to the degree of freedom (CMIN/DF), five additional goodness-of-fit (GOF) measures were computed to assess whether the measurement model is fit with the sample drawn based on the proposed theories. According to Byrne (2010), Kline (2011), Loehlin (2004), Marcoulides and Schumacker (2001) and Segars and Grover (1998), these GOF measures include Goodness-of-Fit Index (GFI), Adjusted Goodness-of-Fit Index (AGFI), Non-Normed Fit Index (NNFI or TLI), Comparative Fit Index (CFI) and Root Mean Square Error of Approximation (RMSEA).

For the CFA (measurement model), as indicated in Table 5, the ratio of the minimum discrepancy (CMIN) to the degree of freedom (DF) for this model was $2.286(p<.05)$ which is smaller than 3 as recommended by Byrne (2010). Other model fit indices include GFI $=0.91$; AGFI $=0.87$, NNFI (also called TLI) $=$ $0.93, \mathrm{CFI}=0.95, \mathrm{SRMR}=0.05$; and RMSEA $=0.07$ with insignificant PCLOSE value. All values exceeded the suggested cut-off level as described by different authors (shown in the Table 5). For a complex model with a number of observed variables, it is unrealistic to have the values of GOF measures above 0.90 (Hair et al., 2010). The combination of these results suggests that the CFA (measurement model) appears to show a good fit between the observed and unobserved variables (Byrne, 2010). The following section describes structural equation modeling used in the study. 
Table 5

Measures of the Model Fit (CFA and SEM Models)

\begin{tabular}{|c|c|c|c|c|c|c|c|c|c|c|}
\hline $\begin{array}{l}\text { Goodness-of-fit } \\
\text { measures }\end{array}$ & CMIN & $\mathrm{DF}$ & $\begin{array}{l}\mathrm{CMIN} / \\
\mathrm{DF}\end{array}$ & $\mathrm{p}$ value & GFI & AGFI & TLI & CFI & RMSEA & ECVI \\
\hline $\begin{array}{l}\text { Recommended } \\
\text { Value }\end{array}$ & & & $<3^{\mathrm{a}}$ & $>0.05^{\mathrm{b}}$ & $\geq 0.90^{\mathrm{a}}$ & $\geq 0.85^{\mathrm{c}}$ & $\geq 0.90^{\mathrm{d}}$ & $\geq 0.95^{\mathrm{c}}$ & $\leq 0.08^{\mathrm{e}}$ & $\begin{array}{l}\text { Lowest } \\
\text { Valueg }^{\mathrm{g}}\end{array}$ \\
\hline $\begin{array}{l}\text { CFA } \\
\text { Measurement } \text { Model }^{\mathrm{f}}\end{array}$ & 242.278 & 106 & 2.29 & 0.00 & 0.91 & 0.87 & 0.93 & 0.95 & 0.07 & 1.269 \\
\hline $\begin{array}{l}\text { SEM Structural } \\
\text { Model }^{\mathrm{f}}\end{array}$ & 192.714 & 104 & 1.85 & 0.00 & 0.92 & 0.89 & 0.96 & 0.97 & 0.057 & 1.097 \\
\hline
\end{tabular}

Notes: $\mathrm{CMIN}=$ Minimum Discrepancy (Chi-Square); DF = Degree of Freedom; GFI = Goodness of Fit Index; AGFI = Adjusted Goodness of Fit Index; TLI = Tucker-Lewis Index; CFI = Comparative Fit Index; RMSEA = Root Mean Square Error of Approximation. $\mathrm{a}=$ Byrne (2010); $\mathrm{b}=$ Hair et al. (2010, p. 647) stated that a significant value may be expected (even with good fit) if the sample size is less than 250 with 12 to 30 observed variables; $c=$ Bagozzi and Yi (1988); $d$ = Bentler and Bonett (1980); $\mathrm{e}=$ Browne and Cudeck (1993); $\mathrm{f}=$ The model is recursive (unidirectional). All values are rounded to two decimal places; $\mathrm{g}=$ no determined appropriate range of values (Herscovitch \& Meyer, 2002, p. 479).

\section{Structural Relationship between Leader-Member Exchange, Interpersonal Relationship, Individual Feeling of Energy, Creative Work Involvement and Turnover Intention}

It is important to note that if the study uses six separate multiple regression equations, it could increase Type-I error i.e. rejecting the true null hypothesis (Sherry \& Henson, 2005). After dividing the standard 95 percent confidence level (i.e. $p<.05$ ) by the total number of dependent (or endogenous) variables (i.e. four in case of this study), called 'Bonferroni Adjustments', the Type-I error may be controlled. However, Pallant (2001) argued that both Type-I and TypeII errors are inversely proportional to each other. In other words, if we reduce the effect of Type-I error using Bonferroni Adjustments, it would simultaneously increase the Type-II error because rests of the other necessary constructs are not used during separate multiple regression analyses. Therefore, structural equation modeling (SEM) method was used to analyse the structural relationship among all of the five constructs without eliminating the effect of any of the constructs during hypothesis testing. SEM is a large sample technique therefore, the sample size should be greater than 200 for SEM purpose (Lei \& Wu, 2007). In contrast, Hair et al. (2010) recommended the sample size between 50 and 400 will be reasonably appropriate for SEM. A sample of 266 valid responses seems reasonably fine for applying SEM in this study. Once again, AMOS application was used to construct the structural relationship between LMX, interpersonal relationship, individual feeling of energy, creative work involvement, and turnover intention. It produced the structural model which highlights relations among the unobserved variables (Byrne, 2010). 
Table 5 also tabulates that the structural model has a very good model fit, determined by the Chi square index $(\mathrm{CMIN} / \mathrm{DF})=1.853(p<.05)$ and other indices include $\mathrm{GFI}=0.92, \mathrm{AGFI}=0.89, \mathrm{TLI}=0.96, \mathrm{CFI}=0.97, \mathrm{SRMR}=0.05 ; \mathrm{RMSEA}=0.057$ with insignificant PCLOSE. All of the model-fit indices reasonably exceeded their recommended value, suggesting that the structural model portrays a very good model fit to the sample drawn (Bagozzi \& Yi, 1988; Browne \& Cudeck, 1993; Lin \& Lee, 2005; Sit, Ooi, Lin, \& Chong, 2009). Both measurement and structural models are recursive that hold two rudimentary features: (A) it stipulates the direction of cause from one direction only (unidirectionality) and (B) their error terms (i.e. disturbances) are orthogonal (i.e. uncorrelated) in nature (Byrne, 2010; Kline, 2011). Figure 2 graphically depicts the structural model with respective effect sizes:

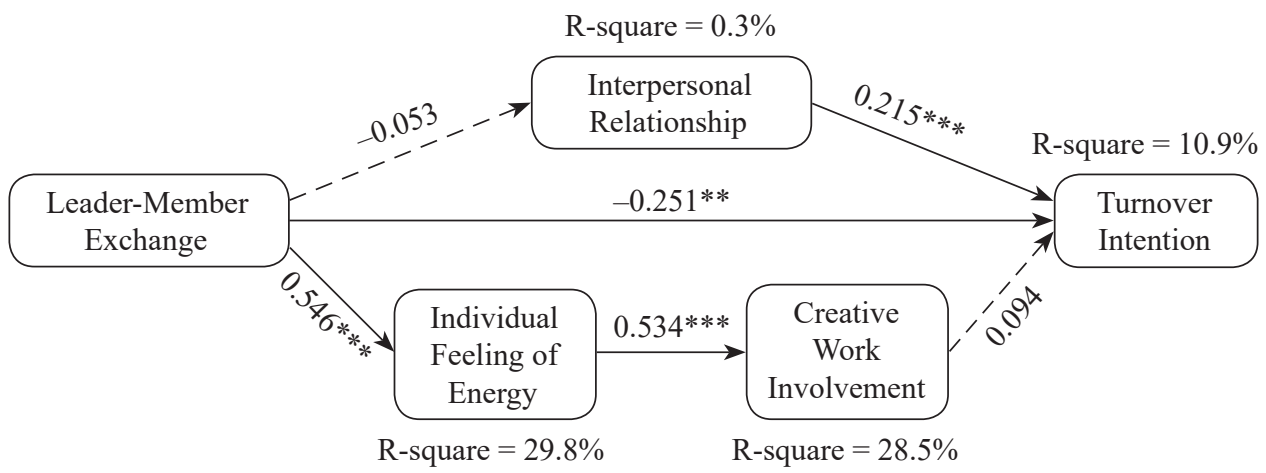

Note: $* * p<.01 ; * * * p<.001$; straight and dotted lines denote statistically significant and insignificant path respectively

Figure 2. Structural Relationship between LMX, Interpersonal Relationship, Individual Feeling of Energy, Creative Work Involvement and Turnover Intention

\section{Generalization of Findings}

Moreover, for the sole purpose of assessing the potential chances of the generalizability of the results, Expected Cross Validation Index (ECVI) was also computed in AMOS. There is no determined appropriate range of values however, lowest values closer to one may indicate that the results holds the characteristics of generalizability (Herscovitch \& Meyer, 2002). Table 5 shows the lowest value of ECVI (i.e. 1.097) for the SEM (structural model) concludes that the results may be generalised on a larger population within the same manufacturing industry in Karachi. 


\section{Hypothesis Testing}

The study posited six hypotheses. It is important to note that complex regression models which were developed by SEM does not however, require to test individual hypothesis. Very recently, Adil (2015) summarized three prime reasons. Therefore, the statistical significance of all the structural parameter values was estimated in the presence of other regression equations to determine the validity of the hypothesized regression paths. The results show that four hypotheses have been found statistically significant to predict the turnover intention from using a combination of LMX, interpersonal relationship, individual feeling of energy, and creative work involvement. Table 6 details the hypothesis testing results which includes SEM regression paths, their standardised and unstandardised regression weights, standard error, critical ratio, $p$-value, and remarks (whether the particular hypothesis is supported in the light of the proposed theory.

Noticeably, the critical ratio was computed by dividing the unstandardized regression weights by its standard error. Byrne (2010) explained that the critical ratio "...operates as a z-statistic in testing that the estimate is statistically different from zero" (p. 68). She added that the value of critical ratio should be greater than $|1.96|$ to make the regression equation statistically significant from zero. To assess the effect size $\left(\mathrm{R}^{2}\right)$, the squared multiple correlations for all of the four effects (or dependent) variables (interpersonal relationship, individual feeling of energy, creative work involvement and turnover intention) were also computed as shown in Figure 2.

\section{DISCUSSION}

The study involves four constructs to predict turnover intention at different levels. These four constructs include LMX relationship, interpersonal relationships, individual feeling of energy, and creative work involvement. After ensuring that the outcomes of the study is not inflated by common method variance bias, six hypotheses are tested by using SEM method in AMOS version 22. These four constructs explain approximately over $11 \%$ of the total variance in explaining turnover intention (Figure 2). The managerial implications of each of the supported hypotheses are discussed below.

LMX relationship has three endogenous variables in this study viz. interpersonal relationship, turnover intention, and individual feeling of energy. The overall results of the structural analysis indicate that LMX has significant negative relationship with employee's turnover intention (standardised regression estimate $=-0.251$, 


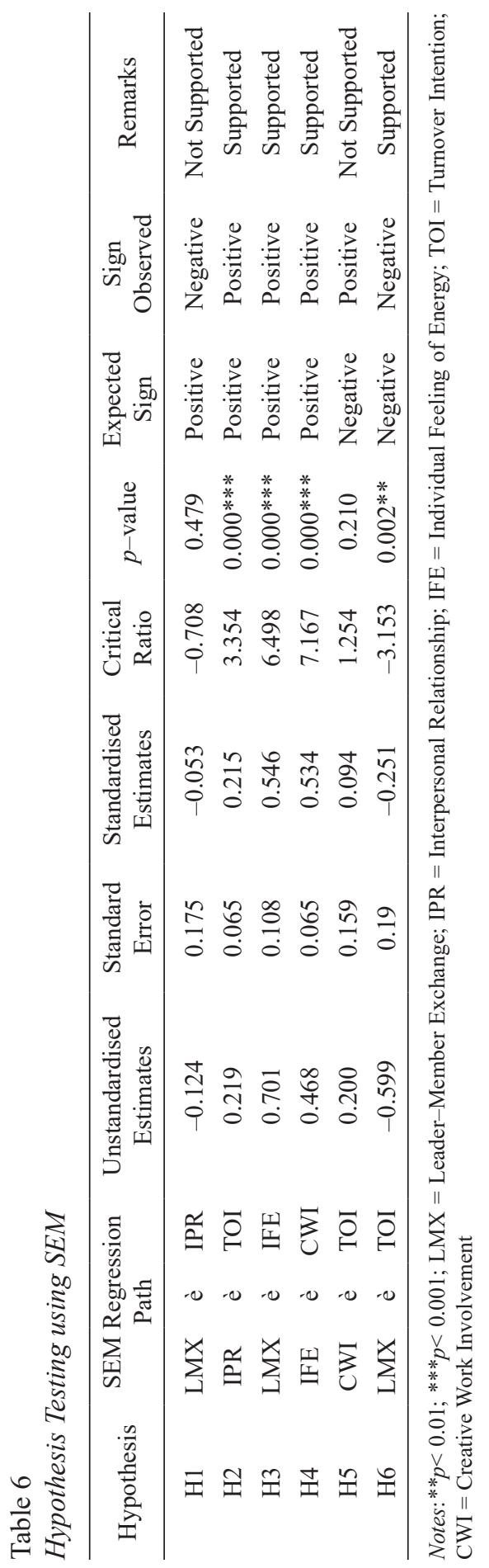


$p=.002$ ) in the manufacturing companies of Karachi (Pakistan). Besides, the results of SEM show that LMX is positively related with individual feeling of energy $(0.546, p=.000)$ which is in turn, positively related to predict creative work involvement. Moreover, interpersonal relationship has shown a significant positive impact on turnover intention. Figure 2 shows that LMX relationship alone explains $29.8 \%$ of variance in predicting individual feeling of energy. Similarly, individual feeling of energy explains $28.5 \%$ of variance in predicting creative work involvement. With the help of standardised parameter estimates, the following section discusses the four hypotheses which have been found statistically significant in predicting its respective endogenous variables.

First, the statistical results reveal that LMX has significant negative relationship with employee's turnover intention thus, the Hypothesis 6 is supported. In fact, high-quality LMX relationship makes an attempt to eradicate power distance between leaders and subordinates. Employees consider this relationship very useful for their career growth. As a result, they raise a number of queries to address their work-related doubts and share creative ideas too. Subordinates start to believe that they have a strong professional bond with their superiors which could expectedly allow them to gain access to meaningful resources. These types of competitive resources may not be accessible to out-group employees having low-quality LMX relationship. This is due to their high-quality relationship which enables them to earn more privileges, priorities, recommendations, endorsements, and preferences. Leaders prefer to share innovative ideas for the mental growth and professional development of in-group subordinates, in particular. Consequently, subordinates enjoy their stay in the organisation as long as they are supervised by the same leadership thus they tend to avoid leaving the organisation.

Second, it was determined from the results that LMX is positively related with individual feeling of energy therefore, the Hypothesis 3 is supported. A great deal of careful efforts are required by the leadership to motivate employees so that they could perform at their optimum level on time. This desire may only come true when subordinates intrinsically feel energy to produce better in accordance with management and business needs. In addition to limited resources available to the organisational members, leadership should make sure that their followers should continue to feel a sense of energy so that they could realise annual targets on time with better cost-efficient ideas. Therefore, it is essential to work on improving individual feeling of energy in order to observe desired results on time.

Third, the research findings elaborate that individual feeling of energy is positively related with creative work involvement $(0.534, p=.000)$ hence, the Hypothesis 4 is supported. As discussed earlier, employees tend to perform better on time when 
they feel energy to perform better. In fact, individual feeling of energy drives a high level of motivation among subordinates which could help them involve in bringing creative ideas for better work efficiencies. Moreover, this energy also enables them to socialise with peer workers in order to rectify work-related problems. As a result, they initiate a wide spectrum of knowledgebase across the organisation which could in turn, help them grow their managerial and administrative capabilities.

Last, the results provide strong evidence that interpersonal relationship is positively related with turnover intention $(0.215, p=.000)$ thus, the Hypothesis 2 is supported. This may be because of the fact that improved interpersonal relationship leads to generate a wide range of interpersonal contacts with different people connected with the organisation. Thus, people may often get knowledge about better job opportunities by virtue of maintaining this strong social networking. As a result, there is likelihood to also increase the turnover intention.

\section{Theoretical Contributions}

This study makes two unique theoretical contributions in the context of the manufacturing companies in Karachi: A) LMX can be negatively related with interpersonal relationship; and B) creative work involvement is also found positively related with turnover intention. Besides, few studies (e.g., Schyns, Torka, \& Gossling, 2007; Vecchio \& Norris, 1996) revealed that the link between LMX and employee turnover had been weak and unstable statistically. On the contrary, this study shows a very strong link between the two $(-0.251, p=.002)$.

\section{Limitations and Directions for Future Research}

The findings of the study should be viewed in the light of the following limitations that may be taken into consideration to improve future studies:

First, instead of longitudinal, the study used a cross-sectional research design to answer research question. Despite the fact that both CFA and SEM models are 'recursive' in nature showing unidirectionality (see superscript point ' $f$ ' in Table 5), both models do not determine the cause-effect-relationship among the constructs (Martinez-Costa \& Jimenez-Jimenez, 2009; Tippins \& Sohi, 2003) that is beyond the scope of the study. Therefore, the present study demonstrates the presence of positive/negative and significant/insignificant association between variables. In contrast, a longitudinal research designs could be more constructive than crosssectional designs when it comes to provide cause-effect-relationship between LMX, interpersonal relationship, individual feeling of energy, creative work involvement and turnover intention. 
Second, the sample was drawn from the manufacturing companies operating in Karachi that is the largest business hub of Pakistan. Considering the expected cross-validation index (ECVI) value (Table 5), the results may only be generalised to a larger population within the same manufacturing industry in Karachi. Future studies may draw a large sample from other cities of Pakistan e.g., Faisalabad, Lahore, Gujrat, etc.

Last, before applying multivariate data analysis, the study used Harman's single-factor test to assess common method variance (CMV) bias in the dataset. Alternately, future studies may use common-latent factor (CLF) method or marker variable while designing the research instrument (Podsakoff et al., 2012) to figure out CMV bias, if any.

\section{CONCLUSION}

The purpose of this study is to investigate the associations between leader-member exchange, interpersonal relationship, individual feeling of energy, creative work involvement, and turnover intention in the manufacturing sector of Karachi. The empirical findings have shown that LMX has significant negative relationship with employee's turnover intention. LMX is positively related with individual feeling of energy which is further positively related with creative work involvement. Interpersonal relationship has shown a significant positive association with turnover intention. On the contrary, LMX has shown statistically insignificant relationship to predict interpersonal relationship (having a very low effect size i.e. 0.3 percent (Figure 2). Likewise, creative work involvement has been found insignificant in predicting turnover intention in the manufacturing companies of Karachi. According to the standardised parameter estimates (Table 6), LMX shows the highest impact on individual feeling of energy $(0.546, p<.001)$ followed by the impact of individual feeling of energy on creative work involvement $(0.534$, $p<.001)$. However, among all of the three 'direct' antecedents of turnover intention, LMX has shown the greatest impact $(-0.251, p<.01)$.

\section{REFERENCES}

Abbasi, S., \& Hollman, K. (2000). Turnover: The real bottom-line. Public Personnel Management, 29(3), 333-342. https://doi.org/10.1177/009102600002900303

Adil, M. S. (2014). Impact of leader's change-promoting behavior on readiness for change: A mediating role of organizational culture. Journal of Management Sciences, 1(2), 113-150. https://doi.org/10.20547/jms.2014.1401202 
Adil, M. S. (2015). Strategic human resource management practices and competitive priorities of the manufacturing performance in Karachi. Global Journal of Flexible Systems Management, 16(1), 37-61. https://doi.org/10.1007/s40171-014-0084-7

Aghazadeh, S. (1999). Human resource management: Issues and challenges in the new millennium. Management Research News, 22, 19-32. https://doi. org/10.1108/01409179910781904

Amabile, T. M. (1983). The social psychology of creativity. New York: Springer-Verlag. https://doi.org/10.1007/978-1-4612-5533-8

Amabile, T. M. (1996). Creativity in context: Update to 'the social psychology of creativity'. Boulder, CO: Westview Press

Amabile, T. M., Schatzel, E. A., Moneta, G. B., \& Kramer, S. J. (2004). Leader behaviors and the work environment for creativity: Perceived leader support. Leadership Quarterly, 15, 5-32. https://doi.org/10.1016/j.leaqua.2003.12.003

Anderson, J. C., \& Gerbing, D. W. (1982). Some methods for respecifying measurement models to obtain unidimensional construct measurement. Journal of Marketing Research, 19(4), 453-460. https://doi.org/10.2307/3151719

Anderson, J. C., \& Gerbing, D. W. (1988). Structural equation modeling in practice: A review and recommended two-step approach. Psychological Bulletin, 103(3), 411-423. https://doi.org/10.1037/0033-2909.103.3.411

Andersson, L. M., \& Bateman, T. S. (1997). Cynicism in the workplace: Some causes and effects. Journal of Organizational Behavior, 18, 449-469. https://doi.org/10.1002/ (SICI)1099-1379(199709)18:5<449::AID-JOB808>3.0.CO;2-O

Ansari, M. A. (1986). Need for nurturant-task leaders in India: Some empirical evidence. Management and Labor Studies, 11(1), 26-36.

Ansari, M. A., Hung, D. K. M., \& Aafaqi, R. (2007). Leader-member exchange and attitudinal outcomes: Role of procedural justice climate. Leadership \& Organization Development Journal, 28(8), 690-709. https://doi.org/10.1108/ 01437730710835443

Aquino, K., Griffeth, R. W., Allen, D. G., \& Hom, P. W. (1997). Integrating justice constructs into the turnover process: A test of a referent cognitions model. Academy of Management Journal, 40(5), 1208-1227. https://doi.org/10.2307/256933

Ashar, M., Munir, E., \& Hafeez, S. (2013). The impact of perceptions of training on employee commitment and turnover intention: Evidence from Pakistan. International Journal of Human Resource Studies, 3(1), 74-88. https://doi.org/10.5296/ijhrs. v3i1.2924

Ashforth, B. E., Harrison, S. H., \& Corley, K. G. (2008). Identity in organizations: An examination of four fundamental questions. Journal of Management, 34(3), 325374. https://doi.org/10.1177/0149206308316059

Ashraf, Z., Jaffri, A. M., Riaz, M., \& Khan, M.A. (2012). The relationship of leader-member exchange and organizational citizenship behavior: The moderating impact of the role of subordinate LMX. European Journal of Business and Management, 4(4), $110-116$.

Atwater, L., \& Carmeli, A. (2009). Leader-member exchange, feelings of energy, and involvement in creative work. The Leadership Quarterly, 20(3), 264-275. https://doi.org/10.1016/j.leaqua.2007.07.009 
Aulakh, P. S., \& Gencturk, E. F. (2000). International principal-agent relationships-control, governance and performance. Industrial Marketing Management, 29, 521-538. https://doi.org/10.1016/S0019-8501(00)00126-7

Bae, J. (1997). Beyond seniority-based systems: A paradigm shift in Korean HRM? Asia Pacific Business Review, 3(4), 82-110. https://doi.org/10.1080/136023897 00000044

Bagozzi, R. P., \& Yi, Y. (1988). On the evaluation of structural equation model. Journal of Academy of Marketing Science, 16(1), 74-94. https://doi.org/10.1007/ BF02723327

Bauer, T. N., \& Green, S. G. (1996). Development of leader-member exchange: A longitudinal test. Academy of Management Journal, 39(6), 1538-1567. https:// doi.org/10.2307/257068

Baumeister, R. F., \& Leary, M. R. (1995). The need to belong: Desire for interpersonal attachments as a fundamental human motivation. Psychological Bulletin, 117, 497-529. https://doi.org/10.1037/0033-2909.117.3.497

Blader, S. L., \& Tyler, T. R. (2009). Testing and extending the group engagement model: Linkages between social identity, procedural justice, economic outcomes, and extra role behavior. Journal of Applied Psychology, 94(2), 445-464. https://doi. org/10.1037/a0013935

Becker, B. E., \& Huselid, M. A. (2006). Strategic human resources management: Where do we go from here? Journal of Management, 32(6), 898-925. https://doi. org/10.1177/0149206306293668

Browne, M. W., \& Cudeck, R. (1993). Alternative ways of assessing model fit. Newbury Park, CA: Sage Publications.

Bryman, A. (2008). Social research methods. New York: Oxford University Press.

Bushra, A. (2012). Job satisfaction and women's turnover intentions in Pakistan's public universities. The Lahore Journal of Business, 1(1), 59-77.

Byrne, B. M. (2010). Structural equation modeling with AMOS: Basic concepts, applications, and programming. New York: Routledge.

Cacioppo, J. T., \& Patrick, W. (2008). Loneliness: Human Nature and the Need for Social Connection. New York: W.W. Norton.

Cacioppo, J. T., Hawkley, L. C., Ernst, J. M., Burleson, M., Berntson, G. G., Nouriani, B., and Spiegel, D. (2006), Loneliness within a nomological net: An evolutionary perspective, Journal of Research in Personality, 40, 1054-1085. https://doi. org/10.1016/j.jrp.2005.11.007

Carmeli, A., \& Schaubroeck, J. (2007). The influence of leaders' and other referents' normative expectations on individual involvement in creative work. The Leadership Quarterly, 18, 35-48. https://doi.org/10.1016/j.leaqua.2006.11.001

Cropanzano, R., \& Mitchell, M. S. (2005). Social exchange theory: An interdisciplinary review. Journal of Management, 31(6), 874-900. https://doi. org/10.1177/0149206305279602

Dansereau, F., Graen, G., \& Haga, W. (1975). A vertical dyad approach to leadership within formal organizations. Organizational Behavior and Human Performance, 13, 4678. https://doi.org/10.1016/0030-5073(75)90005-7 
Darrow, S. M., Callaghan, G. C., Bonow, J. T., \& Follette, W. C. (2014). The functional idiographic assessment template-questionnaire (FIAT-Q): Initial psychometric properties. J. Contextual. Behav. Sci., 3(2), 1-51. https://doi.org/10.1016/j. jcbs.2014.02.002

Darvish, H., \& Dokht, N. F. (2011). Studying the effect of Leader-Member Exchange in creating energy and creativity at workplace: A case study at Alzahra University. International Journal of Academic Research, 3, 125-1259.

Davis, W. D., \& Gardner, W. L. (2004). Perceptions of politics and organizational cynicism: An attributional and leader-member exchange perspective. The Leadership Quarterly, 15(4), 439-465. https://doi.org/10.1016/j.leaqua.2004.05.002

Dienesch, R. M., \& Liden, R. C. (1986). Leader-member exchange model of leadership: A critique and further development. Academy of Management Review, 11, 618-634.

Dillman, D. A. (1978). Mail and telephone surveys. Wiley Interscience.

Doyague, M. F., \& Nieto, M. (2012). Individual creativity performance and the quality of interpersonal relationships. Industrial Management \& Data Systems, 112, 125145. https://doi.org/10.1108/02635571211193671

Dulebohn, J. H., Bommer, W. H., Liden, R. C., Brouer, R. L., \& Ferris, G. R. (2012). A meta-analysis of antecedents and consequences of leader-member exchange integrating the past with an eye toward the future. Journal of Management, 38(6), 1715-1759. https://doi.org/10.1177/0149206311415280

Dutton, J. E. (2003). Energize your workplace: How to build and sustain high-quality relationships at work. San Francisco, CA: Jossey-Bass.

Eatough, E. M., Chang, C. H., Miloslavic, S. A., \& Johnson, R. E. (2011). Relationships of role stressors with organizational citizenship behavior: A meta-analysis. Journal of Applied Psychology, 96, 619-632. https://doi.org/10.1037/a0021887

Eisenberger, R., Stinglhamber, F., Vandenberghe, C., Sucharski, I. L., \& Rhoades, L. (2002). Perceived supervisor support: Contributions to perceived organizational support. Journal of Applied Psychology, 87, 565-573. https://doi.org/10.1037/00219010.87.3.565

Elanain, H. M. (2014). Leader-member exchange and intent to turnover: Testing a mediatedeffects model in a high turnover work environment. Management Research Review, 37, 110-129. https://doi.org/10.1108/MRR-09-2012-0197

Ferris, G. R. (1985). Role of leadership in the employee withdrawal process: A constructive replication. Journal of Applied Psychology, 70, 777-781. https://doi. org/10.1037/0021-9010.70.4.777

Ferris, D. L., Brown, D. J., \& Heller, D. (2009). Organizational supports and organizational deviance: The mediating role of organization-based self-esteem. Organizational Behavior and Human Decision Processes, 108(2), 279-286. https://doi. org/10.1016/j.obhdp.2008.09.001

Firth, L., Mellor, D. J., Moore, K. A., \& Loquet, C. (2004). How can managers reduce employee intention to quit? Journal of Managerial Psychology, 19, 170-187. https://doi.org/10.1108/02683940410526127

Forgas, P. (2003). Toxic emotions at work: How compassionate managers handle pain and conflict. Boston: Harvard Business School Press. 
Fornell, C., \& Larcker, D. F. (1981). Evaluating structuring equation models with unobservable variables and measurement error. Journal of Marketing Research, 18(1), 39-50. https://doi.org/10.2307/3151312

Gaertner, S. (1999). Structural determinants of job satisfaction and organizational commitment in turnover models. Human Resource Management Review, 4, 618634. https://doi.org/10.1016/s1053-4822(99)00030-3

Gerstner, C. R., \& Day, D. V. (1997). Meta-analytic review of leader-member exchange theory: Correlates and construct issues. Journal of Applied Psychology, 82(6), 827-844. https://doi.org/10.1037/0021-9010.82.6.827

Ghosh, P., Satyawadi, R., Joshi, J. P., \& Shadman, M. (2013). Who stays with you? Factors predicting employees' intention to stay. International Journal of Organizational Analysis, 21, 288-312. https://doi.org/10.1108/IJOA-Sep-2011-0511

Ghosh, R., Reio Jr, T. G., \& Bang, H. (2013). Reducing turnover intent: Supervisor and co-worker incivility and socialization-related learning. Human Resource Development International, 16(2), 169-185. https://doi.org/10.1080/13678868.2 012.756199

Gilson, L. L., Shalley, C. E., \& Ruddy, T. M. (2005). Creativity and standardization: Complementary or conflicting drivers of team effectiveness? Academy of Management Journal, 48(3), 521-531. https://doi.org/10.5465/AMJ.2005. 17407916

Graen, G. B., \& Uhl-Bien, M. (1995). Relationship-based approach to leadership: Development of leader-member exchange (LMX) theory of leadership over 25 years: Applying a multi-level multi-domain perspective. The leadership quarterly, 6(2), 219-247. https://doi.org/10.1016/1048-9843(95)90036-5

Graen, G. B., \& Cashman, J. F. (1975). A role making model in formal organizations: A developmental approach. In J. G. Hunt, \& L. L. Larson (Eds.), Leadership Frontiers (pp. 143-165). Kent, OH: Kent State Press.

Graen, G. B., \& Scandura, T. A. (1987). Toward a psychology of dyadic organizing. Research in Organizational Behavior, 9, 175-208.

Graen, G. B., Liden, R. C., \& Hoel, W. (1982). Role of leadership in the employee withdrawal process. Journal of Applied Psychology, 67, 868-872. https://doi. org/10.1037/0021-9010.67.6.868

Graen, G. B., Novak, M. A., \& Sommerkamp, P. (1982). The effects of leader-member exchange and job design on productivity and satisfaction: Testing a dual attachment model. Organizational Behavior and Human Performance, 30, 109-131. https://doi.org/10.1016/0030-5073(82)90236-7

Gray, D. E. (2004). Doing research in the real world. London, Sage Publications.

Greene, C. N., \& Organ, D. W. (1973). An evaluation of causal models linking the received role with job satisfaction. Administrative Science Quarterly, 18, 95-103. https://doi.org/10.2307/2391931

Griffeth, R. W., Hom, P. W., \& Gaertner, S. (2000). A meta-analysis of antecedents and correlates of employee turnover: Update, moderator tests, and research implications for the next millennium. Journal of Management, 26(3), 463-488. https://doi.org/10.1177/014920630002600305 
Hackman, J. R., \& Oldham, G. R. (1980). Work Redesign. Reading, MA: Addison-Wesley. Hair, J. F., Black, W. C., Babin, B. J., \& Anderson, R. E. (2010). Multivariate data analysis. Prentice Hall.

Harris, K. J., Kacmar, K. M., \& Witt, L. A. (2005). An examination of the curvilinear relationship between leader-member exchange and intent to turnover. Journal of Organizational Behavior, 26, 363-378. https://doi.org/10.1002/job.314

Herscovitch, L., \& Meyer, J. P. (2002). Commitment to organizational change: Extension of a three-component model. Journal of Applied Psychology, 87, 474-487. https:// doi.org/10.1037/0021-9010.87.3.474

Hirst, G., van Dick, R., \& van Knippenberg, D. (2009). A social identity perspective on leadership and employee creativity. Journal of Organizational Behavior, 30(7), 963-982. https://doi.org/10.1002/job.600

Hofstede, G. (1983). National cultures in four dimensions: A research-based theory of cultural differences among nations. International Studies of Management \& Organization, 13(1-2), 46-74. https://doi.org/10.1080/00208825.1983.11656358

Hom, P., \& Griffeth, R. (1991). A structural equations modeling test of a turnover theory: Cross-sectional and longitudinal analysis. Journal of Applied Psychology, 76, 350-366. https://doi.org/10.1037/0021-9010.76.3.350

Horne, A. L., Plessis, Y. D., \& Nkomo, S. (2015). Role of department heads in academic development: A leader-member exchange and organizational resource perspective. Educational Management Administration \& Leadership, 1-21.

Huselid, M. A. (1995). The impact of human resource management practices on turnover, productivity, and corporate financial performance. Academy of Management Journal, 38(3), 635-872. https://doi.org/10.2307/256741

Imran, A., \& Fatima, J. (2013). Subordinate's perception of LMX and performance proxies. Middle-East Journal of Scientific Research, 18(6), 796-802.

Irfan, U. K., Farhat, U. K., Hamid, K., \& Nawaz, A. (2013). Determining the demographic impacts on the organisational commitment of academicians in the HEIs of DCs like Pakistan. European Journal of Sustainable Development, 2(4), 117-130.

Ishak, N. A., \& Alam, S. S. (2009). Leader-member exchange and organizational citizenship behavior: The mediating impact of self-esteem. International Journal of Business and Management, 4(3), 52-61. https://doi.org/10.5539/ijbm.v4n3p52

Ishaq, M. I., Hussain, N. M., Nawaz, M. M., Asim, A. I., \& Cheema, L. J. (2012). Assessment of LMX as mediator in procedural justice-organizational citizenship behavior relationship. The New Educational Review, 29(3), 202-211.

Ismail, K., Jafri, S. K. A., \& Khurrum, W. (2011). An evaluation of positive organizational behavior in Banking Sector of Pakistan: Role of Organization based self-esteem and Organizational Supports. Far East Journal of Psychology and Business, 4(1), $1-16$.

Jehanzeb, K., Rasheed, A., \& Rasheed, M. F. (2013). Organisational commitment and turnover intentions: Impact of employee's training in private sector of Saudi Arabia. International Journal of Business and Management, 8(8), 79-90. https://doi.org/10.5539/ijbm.v8n8p79 
Jones, W. H. (1982). Loneliness and social behavior. In L. A. Peplau, \& D. Perlman (Eds.) Loneliness: A source book of current theory, research and therapy (pp. 238-254). New York: Wiley.

Jordan, P. J., \& Troth, A. (2011). Emotional intelligence and leader member exchange: The relationship with employee turnover intentions and job satisfaction. Leadership \& Organization Development Journal, 32(3), 260-280. https://doi. org/10.1108/01437731111123915

Kailasapathy, P., Kraimer, M. L., \& Metz, I. (2014). The interactive effects of leader-member exchange, gender and spouse's gender role orientation on work interference with family conflict. The International Journal of Human Resource Management, 25(19), 2681-2701. https://doi.org/10.1080/09585192.2014.891637

Kashif, M., Khan, Y., \& Rafi, M. (2011). An exploration of the determinants of OCB in the telecommunication sector of Pakistan. Asian Journal of Business Management, 3(2), 91-97.

Khan, I., Nawaz, A., Khan, S., Khan, F., Khan, S., \& Yar, N. B. (2014). The impact of organisational commitment (OC) on the intention to leave (ITL) among the academicians in higher educational institutions (HEIs) in Pakistan. International Journal of Academic Research in Business and Social Sciences, 4(2), 243-254.

Kline, R. B. (2011). Principles and practice of structural equation modeling. New York: The Guilford Press.

Kristof-Brown, A. L., Zimmerman, R. D., \& Johnson, E. C. (2005). Consequence of individuals' fit at work: A meta-analysis of person-job, person-organization, person-group, and person-supervisor fit. Personnel Psychology, 58, 242-281. https://doi.org/10.1111/j.1744-6570.2005.00672.x

Kuean, W. L., Kaur, S., \& Wong, E. S. K. (2010). Intention to quit: The Malaysian companies perspectives. Journal of Applied Sciences, 10(19), 2251-2260. https://doi.org/10.3923/jas.2010.2251.2260

Lee, K., Scandura, T., Kim, Y., Joshi, K., \& Lee, J. Y. (2012). Examining leader-member exchange as a moderator of the relationship between emotional intelligence and creativity of software developers. Engineering Management Research, 1(1), 1528. https://doi.org/10.5539/emr.v1n1p15

Lee, S. H., \& Heard, A. (2000). A managerial perspective of the objectives of HRM practices in Singapore: An exploratory study. Singapore Management Review, 22, 65-82.

Leech, N. L., Barett, K. C., \& Morgan, G. A. (2005). SPSS for intermediate statistics: Use and interpretation. New Jersey, United States: Lawrence Erlbaum Associations, Inc.

Lei, P. W., \& Wu, Q. (2007). Introduction to structural equation modeling: Issues and practical considerations. Educational Measurement: Issues and Practice, 26(3), 33-43. https://doi.org/10.1111/j.1745-3992.2007.00099.x

Liden, R. C., \& Graen, G. (1980). Generalizability of the vertical dyad linkage model of leadership. Academy of Management Journal, 23(3), 451-465. https://doi. org/10.2307/255511 
Lin, H. F., \& Lee, G. G. (2004). Perceptions of senior managers toward knowledge sharing behaviour. Management Decision, 42(1), 108-125. https://doi. org/10.1108/00251740410510181

Lin, H.-F., \& Lee, G.-G. (2005). Impact of organizational learning and knowledge management factors on e-business adoption. Management Decision, 43(2), 171188. https://doi.org/10.1108/00251740510581902

Liu, Z., Cai, Z., Li, J., Shi, S., \& Fang, Y. (2013). Leadership style and employee turnover intentions: A social identity perspective. Career Development International, 18, 305-324. https://doi.org/10.1108/CDI-09-2012-0087

Loehlin, J. C. (2004). Latent variable models: An introduction to factor, path, and structural equation analysis. Mahwah, NJ: Lawrence Erlbaum Associates, Inc.

Marcoulides, G. A., \& Schumacker, R. E. (2001). New developments and techniques in structural equation modeling. Mahwah, NJ: Lawrence Erlbaum Associates, Inc.

Martinez-Costa, M., \& Jimenez-Jimenez, D. (2009). The effectiveness of TQM: The key role of organizational learning in small businesses. International Small Business Journal, 27(1), 98-125. https://doi.org/10.1177/0266242608098348

Meyer, J. P., \& Allen, N. J. (1997). Commitment in the workplace: Theory, research, and application. Thousand Oaks, CA: Sage Publications.

Michel, J. W., \& Tews, M. J. (2016). Does Leader-Member Exchange Accentuate the Relationship Between Leader Behaviors and Organizational Citizenship Behaviors? Journal of Leadership and Organizational Studies, 23(1), 13-26. https://doi.org/10.1177/1548051815606429

Molina, L. M., Montes, J. L., \& Ruiz-Moreno, A. (2007). Relationship between quality management practices and knowledge transfer. Journal of Operations Management, 25(3), 682-701. https://doi.org/10.1016/j.jom.2006.04.007

Morrow, P. C., Suzuki, Y., Crum, M. R., Ruben, R., \& Pautsch, G. (2005). The role of leadermember exchange in high turnover work environments. Journal of Managerial Psychology, 20, 681-694. https://doi.org/10.1108/02683940510631444

Nazir, M. S., Aslam, M. S., \& Nawaz, M. M. (2011). Mediating role of LMX in distributive justice-organizational citizenship behavior relationship: Evidence from Pakistan. European Journal of Social Sciences, 25(3), 59-68.

Northouse, P. G. (2013). Leadership: Theory and practice (6th ed.). Thousand Oaks, CA: SAGE Publications.

Olkkonen, M. E., \& Lipponen, J. (2006). Relationships between organizational justice, identification with organization and work unit, and group-related outcomes. Organizational Behavior and Human Decision Processes, 100(2), 202-215. https://doi.org/10.1016/j.obhdp.2005.08.007

Organ, D. W., \& Greene, C. N. (1981). The effects of formalization on professional involvement: A compensatory process approach. Administrative Science Quarterly, 26, 237-252. https://doi.org/10.2307/2392471

Örtqvist, D., \& Wincent, J. (2006). Prominent consequences of role stress: A meta-analytic review. International Journal of Stress Management, 13, 399-422. https://doi. org/10.1037/1072-5245.13.4.399

Pallant, J. (2001). SPSS survival manual. Philadelphia: Open University Press. 
Podsakoff, N. P., LePine, J. A., \& LePine, M. A. (2007). Differential challenge stressorhindrance stressor relationships with job attitudes, turnover intentions, turnover, and withdrawal behavior: A meta-analysis. Journal of Applied Psychology, 92, 438-454. https://doi.org/10.1037/0021-9010.92.2.438

Podsakoff, P. M., MacKenzie, S. B., \& Podsakoff, N. P. (2012). Sources of method bias in social science research and recommendations on how to control it. Annual Review of Psychology, 65, 539-569. https://doi.org/10.1146/annurevpsych-120710-100452

Polewsky, S., \& Will, H. (1996). Creativity in workshops: Tools for innovation in organizations? European Journal of Work and Organizational Psychology, 5(1), 43-51. https://doi.org/10.1080/13594329608414838

Quinn, R. W. (2007). Energizing others in work connections. In J. E. Dutton, \& B. R. Ragins (Eds.), Exploring positive relationships at work: Building a theoretical and research foundation (pp. 73-90). Mahwah, NJ: Lawrence Erlbaum Associates.

Quinn, R. W., \& Dutton, J. E. (2005). Coordination as energy-in-conversation. Academy of Management Review, 30(1), 36-57. https://doi.org/10.5465/AMR.2005.15281422

Riketta, M. (2005). Organizational identification: A meta-analysis. Journal of Vocational Behavior, 66(2), 358-384. https://doi.org/10.1016/j.jvb.2004.05.005

Rogers, C. R. (1962). The interpersonal relationship: The core of guidance. Harvard Educational Review, 32(4), 416-429.

Rook, K. S. (1984). Promoting Social Bonding. American Psychologist, 39, 1389-1407. https://doi.org/10.1037/0003-066X.39.12.1389

Rotenberg, K. J., Addis, N., Betts, L. R., Corrigan, A., Fox, C., Hobson, Z., Rennisonm, S., Trueman, M., \& Boulton, M. J. (2010). The relation between trust beliefs and loneliness during early childhood, middle childhood, and adulthood. Personality and Social Psychology Bulletin, 36(8), 1086-1100. https://doi. org/10.1177/0146167210374957

Saeed, I., Waseem, M., Sikander, S., \& Rizwan, M. (2014). The relationship of turnover intention with job satisfaction, job performance, leader member exchange, emotional intelligence and organizational commitment. International Journal of Learning and Development, 4(2), 242-256. https://doi.org/10.5296/ijld.v4i2.6100

Salleh, R., Nair, M. S., \& Harun, H. (2012). Job satisfaction, organisational commitment, and turnover intention: A case study on employees of a retail company in Malaysia. World Academy of Science, Engineering and Technology, 72, 316-323.

Scandura, T. A., \& Graen, G. B. (1984). Moderating effects of initial leader-member exchange status on the effects of a leadership intervention. Journal of Applied Psychology, 69, 428-436. https://doi.org/10.1037/0021-9010.69.3.428

Scandura, T. A., Graen, G. B., \& Novak, M. A. (1986). When managers decide not to decide autocratically: An investigation of leader-member exchange and decision influence. Journal of Applied Psychology, 71, 579-584. https://doi. org/10.1037/0021-9010.71.4.579

Schriesheim, C. A. (1979). The similarity of individual-directed and group-directed leader behavior descriptions. Academy of Management Journal, 22, 345-355. https:// doi.org/10.2307/255594 
Schyns, B., Torka, N., \& Gossling, T. (2007). Turnover intention and preparedness for change: Exploring leader-member exchange and occupational self-efficacy as antecedents of two employability predictors. Career Development International, 12(7), 660-679. https://doi.org/10.1108/13620430710834413

Segars, A. H., \& Grover, V. (1998). Strategic information systems planning success: An investigation of the construct and its measurement. MIS Quarterly, 22(2), 139-163. https://doi.org/10.2307/249393

Sharma, R., Crawford, J., \& Yetton, P. (2009). Estimating the effect of common method variance: The method-method pair technique with an illustration from TAM research. MIS Quarterly, 33(3), 1-13.

Shaukat, M. Z., Senin, A. A., \& Ahmed, I. (2012). An exchange perspective of job satisfaction: A study of banking sector of Pakistan. Business Management Dynamics, 1(12), 59-65.

Sherry, A., \& Henson, R. K. (2005). Conducting and interpreting canonical correlation analysis in personality research: A user-friendly primer. Journal of Personality Assessment, 84(1), 37-48. https://doi.org/10.1207/s15327752jpa8401_09

Shirom, A. (2003). Feeling vigorous at work? The construct of vigor and the study of positive affect in organizations. In P. L. Perrewe, \& D. C. Ganster (Eds.), Emotional and physiological processes and positive intervention strategies (pp. 135-164). Bingley: Emerald Group Publishing Limited. https://doi.org/ 10.1016/S1479-3555(03)03004-X

Sit, W. Y., Ooi, K. B., Lin, B., \& Chong, A. Y. L. (2009). TQM and customer satisfaction in Malaysia's service sector. Industrial Management and Data Systems, 109(7), 957-975. https://doi.org/10.1108/02635570910982300

Sparrowe, R. T., \& Liden, R. C. (1997). Process and structure in leader-member exchange. Academy of Management Review, 22(2), 522-552.

Spreitzer, G. M. (1995). Psychological empowerment in the workplace: Dimensions, measurement, and validation. Academy of Management Journal, 38(5), 14421165. https://doi.org/10.2307/256865

Spreitzer, G., Sutcliffe, K., Dutton, J., Sonenshein, S., \& Grant, A. M. (2005). A socially embedded model of thriving at work. Organization Science, 16(5), 537-549. https://doi.org/10.1287/orsc.1050.0153

Sturges, J., Guest, D., Conway, N., \& Mackenzie, D. K. (2002). A longitudinal study of the relationship between career management and organizational commitment among graduates in the first ten years at work. Journal of Organizational Behavior, 23, 731-748. https://doi.org/10.1002/job.164

Tabachnick, B. G., \& Fidell, L. S. (2007). Using multivariate statistics. New York: Pearson. Tharenou, P., Donohue, R., \& Cooper, B. (2007). Management research methods. Cambridge, MA: Cambridge University Press. https://doi.org/10.1017/CBO97 80511810527

Tierney, P., Farmer, S. M., \& Graen, G. B. (1999). An examination of leadership and employee creativity: The relevance of traits and relationships. Personnel Psychology, 52, 591-620. https://doi.org/10.1111/j.1744-6570.1999.tb00173.x 
Tippins, M. J., \& Sohi, R. S. (2003). IT competency and firm performance: Is organizational learning a missing link? Strategic Management Journal, 24(8), 745-761. https:// doi.org/10.1002/smj.337

Tyler, T. R., \& Blader, S. L. (2000). Cooperation in groups: Procedural justice, social identity, and behavioral engagement. London: Psychology Press.

Van Knippenberg, D., \& Ellemers, N. (2003). Social identity and group performance: Identification as the key to group-oriented effort. In S. A. Haslam, D. Van Knippenberg, M. J. Platow, \& N. Ellemers (Eds.), Social identity at work: Developing theory for organizational practice (pp. 29-42). London: Psychology Press, London.

Vecchio, R. P. (1985). Predicting employee turnover from leader-member exchange: A failure to replicate. Academy of Management Journal, 28(2), 478-485. https://doi.org/10.2307/256213

Vecchio, R. P., \& Norris, W. (1996). Predicting employee turnover from performance, satisfaction, and leader-member exchange. Journal of Business and Psychology, 11, 113-125. https://doi.org/10.1007/BF02278260

Volmer, J., Spurk, D., \& Niessen, C. (2012). Leader-member exchange (LMX), job autonomy, and creative work involvement. The Leadership Quarterly, 23, 456465. https://doi.org/10.1016/j.leaqua.2011.10.005

Wang, G., \& Ma, X. (2013). The effects of psychological climate for innovation on salespeople's creativity and turnover intention. Journal of Personal Selling \& Sales Management, 33, 373-387. https://doi.org/10.2753/PSS0885-3134330402

Wang, H., Law, K. S., Hackett, R. D., Wang, D. X., \& Chen, Z. X. (2005). Leader-member exchange as a mediator of the relationship between transformational leadership and followers' performance and organizational citizenship behavior. Academy of Management Journal, 48, 420-432. https://doi.org/10.5465/AMJ.2005.17407908

Woodman, R. W., Sawyer, J. E., \& Griffin, R. W. (1993). Toward a theory of organizational creativity. The Academy of Management Review, 18, 293-321.

Zhang, R. P., Tsingan, L., \& Zhang, L. P. (2013). Role Stressors and job attitudes: A mediated model of leader-member exchange. The Journal of Social Psychology, 153(5), 560-576. https://doi.org/10.1080/00224545.2013.778812

Zhou, J., \& Shalley, C. E. (2003). Research on employee creativity: A critical review and directions for future research. In J. J. Martocchio, \& G. R. Ferris (Eds.), Research in personnel and human resources management (pp. 165-217). Oxford: Elsevier Science Ltd. https://doi.org/10.1016/s0742-7301(03)22004-1 
